\title{
Protein utilization and caecal fermentation in rats fed on wheat-, barley- or naked oat-diets supplemented with $\beta$-glucanase
}

\author{
M. Flis ${ }^{1,3}$, A. Maślanek ${ }^{1}$, Z. Zduńczyk ${ }^{2}$ and J. Juśkiewicz ${ }^{2}$ \\ 'Department of Animal and Feed Management, Warmia and Mazury University in Olsztyn \\ Oczapowskiego 5, 10-718 Olsztyn, Poland \\ 'Institute of Animal Reproduction and Food Research, Polish Academy of Sciences \\ Tuwima 10, 10-718 Olsztyn. Poland
}

(Received 26 April 2004; revised version 29 June 2004; accepted 25 October 2004)

\begin{abstract}
The objective of this study was to determine the biological protein value and rate of fermentation of saccharides in the caecum of rats fed diets containing wheat, hulled barley, or naked oats (cv. Akt), supplemented with $\beta$-glucanase. Sixty rats of an initial body weight of $71.3 \mathrm{~g}$ were fed for 28 days with diets containing 91.8-94.7\% wheat, barley or naked oats, with or without $\beta$-glucanase in the amount of $1000 \mathrm{CU} / \mathrm{kg}$, in subgroups $\mathrm{W}, \mathrm{B}, \mathrm{O}$ and WG, BG, OG, respectively. All of the diets were supplemented with lysine to about $5.5 \mathrm{~g} / 100 \mathrm{~g}$ crude protein, and the barley diets with casein $(3 \%)$. The feed efficiency ratio (FER) and biological value of protein (BV) were determined. At the end of the experiment the rats were euthanized and the caccum isolated. The weight, glycolytic activity and short-chain fatty acid (SCFA) content of caecal digesta were determined.

The FER (gain:feed) of the oat dict was higher than that of the barley-plus-casein or wheat diets and equalled, respectively, $0.202,0.183$, and $0.162 \mathrm{~g} / \mathrm{g}(\mathrm{P}<0.01)$. The $\mathrm{BV}$ of oats was higher than that of wheat $(69.1$ vs $61.7 ; \mathrm{P}<0.01)$, but lower than that of barley plus casein (79.3). Less digesta and digesta dry matter was found in the caecum of rats fed naked oats than wheat and barley (1.34 vs 1.57 and $1.70 \mathrm{~g} / 100 \mathrm{~g} \mathrm{BW}$ and 286 vs 360 and $389 \mathrm{mg} / 100 \mathrm{~g} \mathrm{BW}$, respectively; $\mathrm{P}<0.01$ ). Feeding the oat diet (with the highest fat content) led to a decrease in the activity of many glycolytic enzymes in the caecum. The SCFA concentration in $1 \mathrm{~g}$ of caecum digesta in the animals fed naked oats and wheat was similar and higher than in the animals fed barley, whereas the SCFA pool was lowest in the oat group. The addition of $\beta$-glucanase did not increase the body weight gains of the rats, FER, and BV of the cereals, but did increase the degradation of $\beta$-glucans in the caecum, as indicated by the rise in the caecal SCFA concentration, most distinct in the rats fed the oat diet containing the most $\beta$-glucans.
\end{abstract}

KEY WORDS: naked oats, wheat, hulled barley, $\beta$-glucanase, protein utilization, caecal fermentation, rats

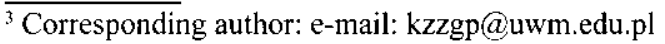




\section{INTRODUCTION}

Husked oats contain a large amount of hulls and therefore, fibre. The components of fibre are poorly digested by poultry and pigs, moreover, they lower the intestinal and total digestibility of other nutrients (Pettersson et al., 1997). As a result, the digestible and metabolizable energy contents of husked oats are low (Petkov et al., 2001) and its use in feeding monogastric animals is consequently limited despite its well-balanced amino acid content and the high biological value of its protein (Macicjewicz-Ryś et al., 1985; Pettersson et al., 1997). The development of naked oats was intended to increase the use of this cereal in the nutrition of highly productive monogastric animals. In comparison with husked oats, naked oats contain less fibre and more ether extract and crude protein. The content of crude protein ranges from 14.2 to $20.2 \%$ DM (Conciatori et al., 2000); the high-protein varieties contain less lysine and other essential amino acids in protein, which has a lower biological value (Valentine, 1987; Van Barneveld et al., 1998).

Despite the dietary fibre content of naked oats being about $50 \%$ lower than in husked oats (Bach Knudsen, 1997), its use in the nutrition of monogastric animals is still limited due to the high content of $\beta$-glucans and soluble dietary fibre (Bach Knudsen, 1997; Givens et al., 2000). The unfavourable physiological effects of these components can be reduced by adding the appropriate enzymes to feeds containing naked oats.

In Poland, oats make up a large share of cereal crops and the area under cultivation with the first varieties of naked oats, Akt and Polar, is increasing. The results of experiments in which cv. Akt grain from seed plantations was used (Kosieradzka and Fabijańska, 2001; Petkov et al., 2001) are not sufficient to evaluate the nutritive and physiological properties of grain from commercial crops of naked oats.

The objective of this study was to determine the influence of diets containing naked oats, wheat or barley, with or without supplementation with $\beta$-glucanase, on growth, feed utilization, biological value of protein and indicators related to the function of the caecum in the rat.

\section{MATERIAL AND METHODS}

\section{Animals and diets}

Commercially cultivated naked oats $\mathrm{cv}$. Akt, winter wheat $\mathrm{cv}$. Wanda, and spring barley cv. Rodos were used. Body weight gain, feed efficiency ratio (FER), true protein digestibility (TD), biological value of protein (BV), and activity of 
glycolytic enzymes and rate of carbohydrate fermentation in the caecum of rats were determined.

The study was conducted on 60 Wistar rats aged 28-30 days and initial body weight of $71.3 \pm 2.5 \mathrm{~g}$. The rats were maintained individually in cages of organic glass in a room with controlled lighting $(12 \mathrm{~h})$, temperature $\left(22-23^{\circ} \mathrm{C}\right)$, and relative humidity (appr. 70\%). For 4 weeks 10 rats in the group were fed diets containing $91.8-94.7 \%$ wheat, barley or naked oats without (groups W, $\mathrm{B}, \mathrm{O}$ ) or with supplementation with $\beta$-glucanase (groups $\mathrm{WG}, \mathrm{BG}$, and $\mathrm{OG}$ ). The diets were supplemented with lysine (to about $5.5 \mathrm{~g} / 100 \mathrm{~g}$ crude protein), standard vitamin-mineral mixture AIN-93G (Reeves, 1997), and an enzyme preparation, Hostazyme C, providing $1000 \mathrm{CU} / \beta$-glucanase $/ \mathrm{kg}$ (Table 1). In order to equalize the protein content $3 \%$ casein was added to the barley diets (B and $\mathrm{BG}$ ).

TABLE 1

Ingredients and nutritional value of the diets used in growth and balance experiment on rats, $\mathrm{g} \mathrm{kg}^{-1}$, as fed basis

\begin{tabular}{|c|c|c|c|c|c|c|}
\hline \multirow{2}{*}{ Item } & \multicolumn{6}{|c|}{ Diet } \\
\hline & W & WG & $\mathrm{B}$ & BG & $\mathrm{O}$ & OG \\
\hline \multicolumn{7}{|l|}{ Ingredients, $\mathrm{g} \mathrm{kg}^{-1}$} \\
\hline wheat & 946 & 946 & - & - & - & - \\
\hline barley & - & - & 918.4 & 918.4 & - & - \\
\hline naked oats & - & - & - & - & 947.5 & 947.5 \\
\hline casein & - & - & 30 & 30 & - & - \\
\hline mineral mixture AIN-93 $\mathrm{G}^{1}$ & 30 & 30 & 30 & 30 & 30 & 30 \\
\hline vitamin mixture AIN-93 $\mathrm{G}^{1}$ & 20 & 20 & 20 & 20 & 20 & 20 \\
\hline potato starch & 1 & - & 1 & - & 1 & - \\
\hline$\beta$-glucanase preparation ${ }^{2}$ & - & 1 & - & 1 & - & 1 \\
\hline L-lysine $\mathrm{HCl}(78 \%)$ & 3 & 3 & 0.6 & 0.6 & 1.5 & 1.5 \\
\hline \multicolumn{7}{|l|}{ Nutrient content, $\mathrm{g} \mathrm{kg}^{-1}$} \\
\hline crude protein ${ }^{3}$ & 108.8 & 109.7 & 101.8 & 102.7 & 112.3 & 113.2 \\
\hline lysine & 5.3 & 5.3 & 5.6 & 5.6 & 5.5 & 5.5 \\
\hline threonine & 2.9 & 2.9 & 3.9 & 3.9 & 3.7 & 3.7 \\
\hline Met + cys & 4.1 & 4.1 & 4.3 & 4.3 & 6.0 & 6.0 \\
\hline tryptophan & 1.1 & 1.1 & 1.2 & 1.2 & 1.3 & 1.3 \\
\hline NDF & 124.5 & 124.5 & 168.2 & 168.3 & 109.0 & 109.0 \\
\hline$\beta$-glucans & 5.7 & 5.7 & 26.5 & 26.5 & 34.8 & 34.8 \\
\hline ether extract $\mathrm{HCl}$ & 24.9 & 24.9 & 22.9 & 22.9 & 80.4 & 80.4 \\
\hline Gross energy, $\mathrm{MJ} / \mathrm{kg}$ & 15.61 & 15.61 & 15.93 & 15.93 & 17.18 & 17.18 \\
\hline
\end{tabular}

${ }^{1}$ Reeves (1997)

${ }^{2}$ enzyme preparation containing $1000 \mathrm{CU} / \mathrm{g}$ endo-1,4-beta-glucanase

${ }^{3}$ crude protein analysed, the other nutrients calculated on the basis of chemical analysis of feed ingredients 
Urine and faeces were collected from 6 rats in each group for 5 days in the fourth week of the experiment to determine TD and protein BV. The amount of excreted endogenous $\mathrm{N}$ in faeces and urine was determined on an additional group of rats of a similar age and body weight, maintained on a protein-free diet. The FER was calculated as the ratio between body weight gain and feed intake during the 4-week growth period (gain/feed; g/g). At the end of the experiment, 8 rats from each subgroup were euthanized, the caecum isolated and weighed, the $\mathrm{pH}$ of its contents measured, and the digesta collected and analysed. The contents of ammonia, dry matter, glycolytic enzyme activity, and short-chain fatty acids (SCFA) were determined. The experimental protocol was approved by the local ethics committee and was in compliance with the recommended principles of euthanasia (Close et al., 1997).

\section{Chemical analyses}

Dry matter, ash, crude protein, ether extract (after $\mathrm{HCl}$ hydrolysis) were determined according to AOAC (1990). Crude fibre (CF), acid detergent fibre (ADF) and neutral detergent fibre (NDF) were estimated using a Fibertec $\mathrm{M}$ apparatus. Gross energy was determined by combustion of feed samples in a KL 10 calorimeter. The $\beta$-glucan content was assayed using Megazyme tests, which employ lichenase and glucosidase to hydrolyse $\beta$-glucan to glucose after previous extraction of free sugars with $80 \%$ ethanol. Glucose from $\beta$-glucan was assayed using a test from Sigma (Infinity Glucose Reagent).

$\mathrm{pH}$ of the caecal contents was measured using a Hanna Instruments $\mathrm{pH}$-meter, ammonia content by the Conway method, glycolytic enzyme activity by the method of Andrieux at al. (1992), short-chain fatty acid (SCFA) content by gas chromatography. The samples were diluted with deionized water, centrifuged at $10000 \mathrm{rpm}$ for $5 \mathrm{~min}$ and the supernatant applied to the column. The analyses were performed using a Schimadzu GC-14A chromatograph with a glass $2.5 \mathrm{~m}$ $\times 2.6 \mathrm{~mm}$ column containing $10 \% \mathrm{SP}-1200 / 1 \% \mathrm{H}_{3} \mathrm{PO}_{4}$ on $80 / 100$ Chromosorb W AW. Column temperature was $110^{\circ} \mathrm{C}$, FID temperature, $180^{\circ} \mathrm{C}$, and injection chamber temperature, $195^{\circ} \mathrm{C}$.

\section{Statistical analysis}

The results were subjected to bifactorial analysis of variance ( 3 species of cereals $\times 2$ levels of glucanase). Averages were compared using the StudentNewman Keul procedure at two levels of significance $(\mathrm{P}<0.05 ; \mathrm{P}<0.01)$. The calculations were made using the STATISTICA (v. 6.0) software package. 


\section{RESULTS}

The weight of 1000 grains of naked oats was much smaller than that of wheat and husked barley (Table 2). The proportion of husked grain was $6.9 \%$. In comparison with wheat and barley, naked oats contained somewhat more protein in dry matter ( 13.03 vs 12.73 and $10.37 \%$ ), and much more ether extract ( 9.65 vs 3.01 and $2.88 \%$ ), respectively. It contained little CF, ADF, and NDF: $2.76,3.88$, and $13.08 \%$, respectively. The naked oats grain had the most $\beta$-glucans $(4.17 \%$ DM). The ratio of the $\beta$-glucan content to NDF in oats ( 4.17 vs 13.08 , i.e. $32 \%$ ) was double that in barley $(3.35$ vs 21.25 , i.e. $16 \%)$. The gross energy content of oats was higher than of wheat or barley.

TABLE 2

Weight of 1000 kemels, nutrients (\% DM) and gross energy content in cereal grains used in experiment

\begin{tabular}{lccc}
\hline Item & Wheat & Barley & Naked oats \\
\hline Weight of 1000 kernels, g & 43.2 & 40.6 & 24.2 \\
Husked kemels composition, \% & & & \\
$\quad$ dry matter & 87.35 & 86.19 & 87.95 \\
crude ash & 1.83 & 2.40 & 2.27 \\
crude protein & 12.73 & 10.37 & 13.03 \\
ether extract $\mathrm{HCl}$ & 3.01 & 2.88 & 9.65 \\
crude fibre & 3.03 & 6.38 & 2.76 \\
acid detergent fibre & 4.97 & 7.56 & 3.88 \\
neutral detergent fibre & 15.06 & 21.25 & 13.08 \\
$\beta$-glucans & 0.68 & 3.35 & 4.17 \\
Gross energy, MJ kg-1 DM & 18.89 & 19.27 & 20.63 \\
\hline
\end{tabular}

Feed intake over the 28 days of the experiment was nearly the same and equalled about $620 \mathrm{~g}$ (Table 3 ), whereas body weight gain was highest in the rats fed the naked oats diet, lower in those given barley, and the lowest in the group fed the wheat diet: 125.1, 113.3, and $100.3 \mathrm{~g}$, respectively $(\mathrm{P}<0.01)$. The feed efficiency ratio of the oat diet $(0.202)$ was higher than of the casein-containing barley diet (0.183) and the wheat diet (0.162). The addition of $\beta$-glucanase did not affect feed intake, body weight gain, or feed efficiency ratio.

The rats fed the barley diets excreted significantly more nitrogen in faeces (463 $\mathrm{mg}$ ) than the rats fed the oat and wheat diets, 403 and $359 \mathrm{mg}$, respectively (Table 3 ). The highest true protein digestibility was in the wheat diet, the lowest, in the barley diet despite the addition of casein. The biological value of the protein in naked oats was significantly higher than in wheat (69.1 vs 61.7$)$, but lower than in barley supplemented with casein (79.3). The addition of $\beta$-glucanase increased protein $\mathrm{TD}$, but only when the cereals were compared jointly with or without 


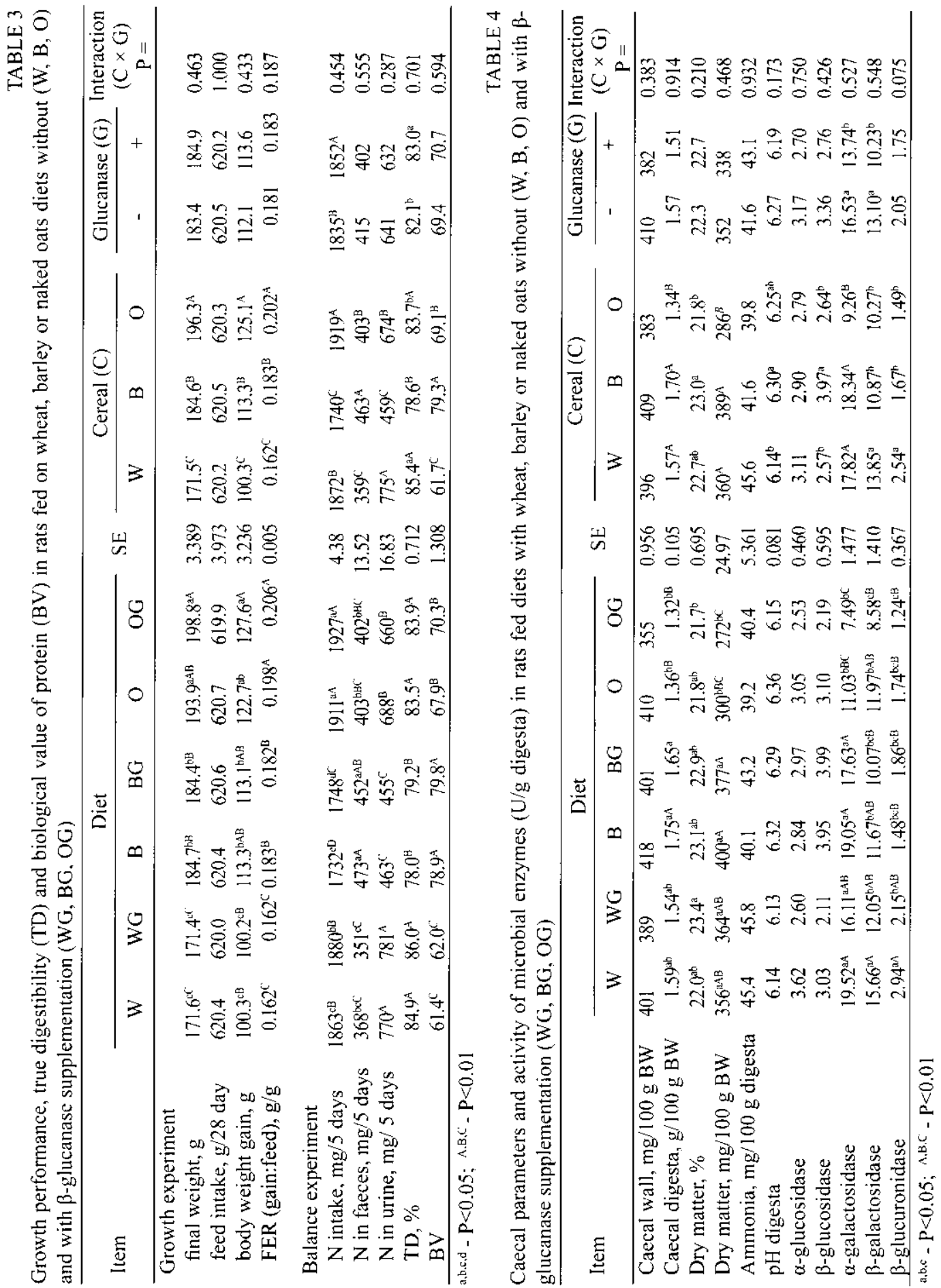


the addition of this enzyme. Supplementation with this enzyme did not affect the biological value of the cereals.

The amount of digesta in the caecum of the rats fed the oat diet was smaller than in the animals that received the wheat diet with similar NDF content (Table 4). In comparison with feeding wheat, feeding naked oats also led to a reduction in the dry matter content of the caecum digesta, especially when expressed in relation to body weight ( $286 \mathrm{vs} 360 \mathrm{mg} / 100 \mathrm{~g} \mathrm{BW} ; \mathrm{P}<0.01$ ). In rats fed the barley diet, which contained the most NDF, a significantly higher amount of digesta in the caecum and a higher dry matter content were found in comparison with rats fed the oat diet, whereas these parameters were insignificantly higher than in rats given the wheat diet. The addition of $\beta$-glucanase did not significantly affect the weight of the caecum (tissue and contents) or the dry matter content in the digesta.

The concentration of ammonia in the caecum contents was similar in all groups. The lowest $\mathrm{pH}$ was found in the digesta of the animals fed the wheat diet, both with and without the addition of $\beta$-glucanase (6.14 and 6.13, respectively), the highest was in the barley (both groups) and naked oats diet (the group without enzyme supplementation). The addition of $\beta$-glucanase to the diet containing naked oats led to a drop in $\mathrm{pH}$ of the caecum contents from 6.36 to $6.15(\mathrm{P}>0.05)$.

The activities of $\alpha$-galactosidase, $\beta$-galactosidase, $\beta$-glucuronidase were lower in the caecal digesta of rats fed naked oats than in those fed wheat, whereas the activities of $\beta$-glucosidase and $\alpha$-galactosidase were lower in comparison with those fed barley. In rats fed the barley diet, which had the highest NDF content, the activity of $\beta$-glucosidase was higher, and the activities of $\beta$-galactosidase and $\beta$-glucuronidase were lower than in the animals fed wheat. The addition of $\beta$-glucanase to the wheat, barley and oat diets significantly lowered the activities of $\alpha$ - and $\beta$-galactosidase and, insignificantly, those of the other enzymes determined in the caecal contents.

The concentration of SCFA per gram of caecal content varied (Table 5). In comparison with feeding barley, feeding naked oats and wheat increased the concentration of total acids $(\mathrm{P}<0.05)$, more distinctly the concentration of propionic acid $(\mathrm{P}<0.01)$ than acetic or butyric acids. The addition of $\beta$-glucanase to cereals increased the concentration of acetic acid $(\mathrm{P}<0.05)$, propionic acid $(\mathrm{P}<0.01)$ and total SCFA in the caecal contents (from 79.70 to $89.14 \mu \mathrm{mol} / \mathrm{g} ; \mathrm{P}<0.05$ ). The addition of glucanase to the oat diet was more effective than to the barley and wheat diets. In rats fed the oat diet, it increased significantly the concentration of propionic acid, and also the concentration of total SCFAs more noticeably (diet OG vs $\mathrm{O}$ by $16.6 \%, \mathrm{P}<0.05$ ), than in those fed the barley (by $12.1 \%$ ) or wheat (by $6.9 \%$ ) diets.

The total pool of SCFA in the caecum of rats fed the oat diet was lower than in those fed wheat and barley diets $(P>0.05)$. The species of cereal used in the diet influenced the SCFA profile in the caecum. Feeding naked oats decreased the proportion of acetic acid $(\mathrm{P}<0.05)$ and increased that of propionic acid $(\mathrm{P}<0.05)$ in comparison with feeding wheat and barley. 


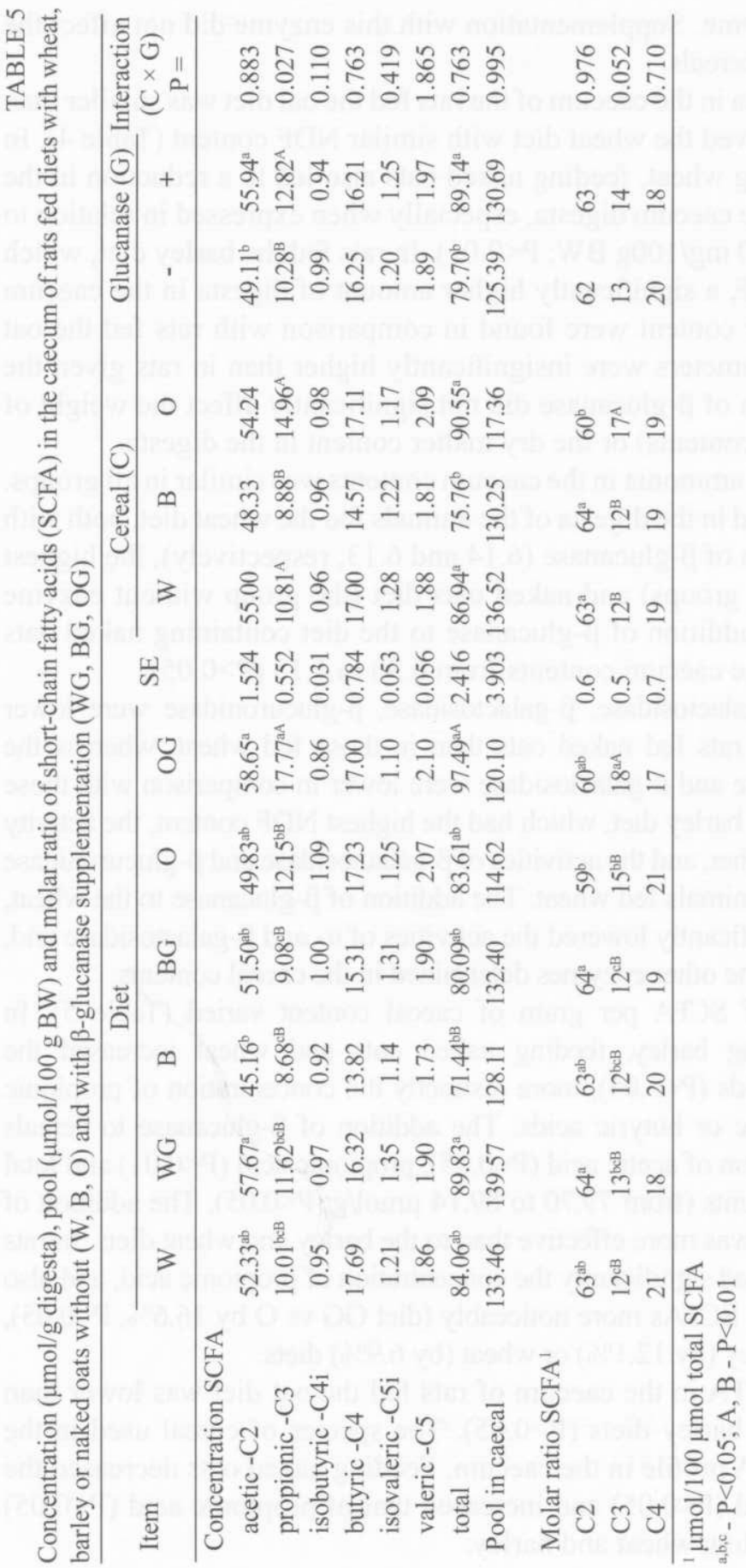


There was no significant interaction between any of the analysed indicators and experimental factors $(\mathrm{P}>0.05)$, which indicates that the addition of glucanase equally affected each of the cereal species.

\section{DISCUSSION}

The naked oat grain used in the experiment was slightly smaller (by $2.1 \mathrm{~g}$ per 1000 grains) than the grain of the same variety from seed crops (COBORU, 2002). The share of husked seeds, which always occur in this form of oats, especially at the base of the ear, can be considered typical in comparison with the values reported in other studies (Christison and Bell, 1980). The crude protein content of the oats was similar to the lowest values found in other experiments (Conciatori et al., 2000), which may have been a result of the environmental conditions under which the crop was grown (poorer soil and less fertilization). The low content of NDF, ADF and CF, lower even than in wheat grain, as well as the high content of hemicellulose (70\%) (the difference between NDF and ADF) indicate that the naked oats contained relatively little fibre that was indigestible in the gastrointestinal tracts of monogastric animals. The $\beta$-glucan content in the analysed Polish variety, Akt, was similar to that in Danish (Bach Knudsen, 1997) and British (Givens et al., 2000) varieties.

The rats fed the oat diets had higher body weight gains and FERs, $10 \%$ higher than in the barley group and $25 \%$ than in the wheat group. The lower growth efficiency of the barley diets in comparison with the oat diets can be explained mainly by the lower energy content of the barley diets, whereas the lowest efficiency of the wheat diets can be explained by both the lower energy as well as protein contents, since they contained the least methionine with cystine, threonine, and tryptophan (Table 1). The results showed that naked oat was a good feed that stimulated the growth of young rats.

The distinctly higher BV of naked oats as compared with that of wheat (61.7 and 69.1 , respectively), was in agreement with other experiments, in which the BV of wheat supplemented with lysine was 62.5, naked oats 78.7 (Kosieradzka and Fabijańska, 2001). In our experiment, the highest BV was found in the rats from the barley group, which should be attributed to the high value of barley protein (Horaczyński, 1989) and the presence of casein in the diet. The addition of $\beta$-glucanase significantly increased the TD of cereal grain, but not to a degree having practical significance (on average by 0.9 percentage points), but did not affect urinary nitrogen excretion, the growth of rats and feed utilization, regardless of the species of cereal.

The smaller amount of caecal digesta and dry matter in rats fed oats indicates that the components of naked oats were more susceptible to digestion before reaching the end of the small intestine than the components of barley or even 
wheat. These results are in agreement with those obtained in pigs, in which ileal digestibility of the dry matter of a wheat diet was $68 \%$, whereas that of a diet with naked oats, $71-76 \%$, and energy digestibility, 74 and $77-81 \%$, respectively (Van Barneveld et al., 1998).

The lower glycolytic activity in the caecum of rats fed the oat diet, in comparison with those on the wheat and barley diets, could have resulted from the oat diet's higher fat content ( 8.04 vs 2.49 and $2.29 \%$ ). It was found that adding fat to the diet of rats lowers enzyme activity and the number of bacteria in the caecum (Mallett et al., 1983). An additional factor could have been the smaller amount of substrate in the caecum of the rats fed the diet with a reduced fibre content. Probably, for this reason the addition of $\beta$-glucanase lowered the activity of microbiological enzymes, especially $\alpha$ - and $\beta$-galactosidase.

The saccharides of naked oats and wheat were more susceptible to fermentation than those of barley, which is indicated by the higher concentration of acetic and propionic acids and total SCFA in the digesta of rats fed diets $\mathrm{O}$ and $\mathrm{W}$. This could have been the result of the lower fibre content in comparison with diet $\mathrm{B}$. In the large intestine of pigs, Pettersson and Lindberg (1997) found higher degradation of the nitrogen-free extractives and dietary fibre of naked barley, which has less fibre than husked barley, 68 and $54 \%$ vs 55 and $33 \%$, respectively. The smaller amount of digesta reaching the caecum of rats fed oats and the high susceptibility of saccharides to fermentation indicate that the components of naked oats are readily available to monogastric animals.

The addition of $\beta$-glucanase increased the susceptibility of saccharides, including $\beta$-glucans, to fermentation in the caecum, as indicated by the significant increase in the SCFA concentration per gram of digesta under the influence of glucanase supplementation, which was most distinct in rats fed naked oats (group OG vs $\mathrm{O}$ ), having the highest $\beta$-glucan content. Microscopic analysis of digesta of pigs (Johansen and Bach Knudsen, 1997) showed that without the addition of glucanase, oat $\beta$-glucan remained in the untouched structures of seed endosperm walls until it reached the distal small intestine, but was completely disrupted in the caecum. The addition of glucanase in our experiment may have accelerated the liberation of $\beta$-glucans from endosperm cell walls in the small intestine, which led to increasing the fermentation rate in the caecum.

The smaller total pool of SCFA in the caecum of rats fed oats was the result of the significantly smaller amount of digesta and dry matter in comparison with the rats fed wheat and barley.

Changes in the acid profile, i.e. the reduction in the proportion of acetic acid and increase proportion of propionic acid in the contents of the caecum of rats fed the diet containing naked oats could have been caused by the greater fat content of this diet. A similar effect of fat on the SCFA profile in digesta in the terminal small intestine and in faeces was found in studies on pigs (Bakker et al., 1996). 


\section{CONCLUSIONS}

The nutritive value of naked oats is high; the feed efficiency ratio (FER) was higher than that of wheat and barley with a small addition of casein; the BV of protein was higher than in wheat. The carbohydrates of naked oats seem to be more susceptible to digestion before reaching the caecum than those of barley or even wheat, which is indicated by the smaller amount of digesta and dry matter in the caecum of rats fed the oat diet. The susceptibility to fermentation of the saccharides of naked oats and wheat in the caecum of rats was similar and higher than in barley. The addition of $\beta$-glucanase did not increase gains, feed efficiency or the biological value of protein of the cereals, but increased the SCFA concentration in caecal contents, most considerably in the rats fed the oat diet, which had the highest $\beta$-glucan content.

\section{REFERENCES}

Andrieux C., Pacheso E.D., Bouchet B., Gallant D., Szylit O., 1992. Contribution of the digestive tract microflora to amylomaize starch degradation in the rat. Brit. J. Nutr. 67, 489-499

AOAC, 1990. Official Methods of Analysis, Association of Official Analytical Chemists. 15 Edition. Arlington, VA

Bach Knudsen K.E., 1997. Carbohydrate and lignin contents of plant materials used in animal feeding. Anim. Feed Sci. Tech. 67, 319-338

Bakker G.C.M., Dekker R.A., Jongbloed R., 1996. Amounts of methane and volatile fatty acids from various combinations of fat and non-starch polysaccharides in growing fattening pigs. G.C.M. Bakker, Interaction between carbohydrates and fat in pigs - impact of energy evaluation of feeds. $\mathrm{PhD}$. Thesis. Institute of Animal Science and Health, Lelystad (The Netherlands), pp. 117-137

Christison G.I., Bell J.M., 1980. Evaluation of Terra, a new cultivar of naked oats (Avena nuda), when fed to young pigs and chicks. Can. J. Anim. Sci. 60, 465-471

Close B., Banister K., Baumans V., Bernoth E.-M., Bromage N., Bunyan J., Erhardt W., Flecknell P., Gregory N., Hackbarth H., Morton D., Warwick C., 1997. Recommendations for euthanasia of experimental animals: Part 2. Lab. Animals 31, 1-32

COBORU, 2002. Central Station of Investigations the Agricultural Plants. Description list of the cultivar varieties. Agricultural Plants (in Polish). Editor: COBORU, Słupia Wielka (Poland), pp. $76-87$

Conciatori A., De Stefanis E., Redaelli R., Sgrulletta D., 2000. Chemical characterization of some kernel traits in naked oat genotypes. J. Genet. Breed. 54, 299-302

Givens D.I., Davies T.W., Laverick R.M., 2000. Dietary fibre fraction in hulled and naked winter oat grain: effect of cultivar and various agronomic factors. J. Sci. Food Agr. 80, 491-496

Horaczyński H., 1989. Estimation of the nutritive value of protein of different varieties of cereals on growing rats (in Polish). Rocz. Nauk rol., B-104 (4), 7-16

Johansen H.N., Bach Knudsen K.E., 1997. Physico-chemical properties and the degradation of oat bran polysaccharides in the gut of pigs. J. Sci. Food Agr. 73, 81-92

Kosieradzka J., Fabijańska M., 2001. Comparison of the nutritive value of naked and husked oat protein with wheat and maize. J. Anim. Feed Sci. 10, Suppl. 2, 309-314 
Maciejewicz-Ryś J., Kosmala I., Zima J., 1985. Complementary effect of legume seeds protein on biological value of grain protein (in Polish). Rocz. Nauk. Zoot., Monogr. Rozpr. 23, 217-227

Mallet A.K., Rowland I.R., Wise A., 1984. Influence of dietary fats on the rat caecal microflora. Proc. Nutr. Soc. 43, 1A

Petkov K., Piech M., Lubowicki R., Lukaszewski Z., Jaskowska I., Biel W., 2001. Evaluation of the nutritive value of naked and husked oat in pig nutrition (in Polish). Rocz. Nauk. Zoot. 28 (2), $165-173$

Pettersson $\AA$., Lindberg J.E., 1997. 1leal and total tract digestibility in pigs of naked and hulled barlcy with different starch composition. Anim. Feed Sci. Tech. 66, 97-109

Pettersson $\AA$., Lindberg J.E., Thomke S., 1997. Nutritive value of oats of different composition evaluated by intact and fistulated pigs. Acta Agr. Scand., Sect. A, Anim. Sci. 47, 247-253

Reeves P.G., 1997. Components of the AIN-93 diets as improvements in the AIN-76A dicts. J. Nutr. $127,838 \mathrm{~S}-841 \mathrm{~S}$

Valentine J., 1987. Breeding cereals of high nutritional quality with special reference to oats and naked oats. Aspects Appl. Biol. 15, 541-548

Van Barneveld R.J., Szarvas S.R., Barr A.R., 1998. The apparent ileal digestibility of amino acids and the digestible energy content of naked oats (Avena sativa cv Bandicoot) fed to growing pigs. J. Sci. Food Agr. 76, 277-284

\section{STRESZCZENIE}

\section{Wykorzystanie bialka i fermentacja w jelicic ślepym szczurów otrzymujących diety $z$ pszenicą, jęczmieniem lub owsem nagim uzupelnione $\beta$-glukanazą}

Celem doświadczenia było zbadanie wartości białka i natężenia fermentacji cukrowców w jelicie ślepym szczurów otrzymujących diety zawierające ziarno pszenicy, jęczmienia oplewionego lub owsa nagiego (odmiany Akt), oraz dodatek $\beta$-glukanazy. 60 szczurów o początkowej m.c. 71,3 g żywiono przez 28 dni dietami zawierającymi $91,8-94,7 \%$ pszenicy, jęczmienia lub owsa nagiego, be $z$ dodatku lub $\mathrm{z}$ dodatkiem $\beta$-glukanazy $\mathrm{w}$ ilości $1000 \mathrm{CU} / \mathrm{kg}$, odpowiednio $\mathrm{w}$ podgrupach $\mathrm{W}$, B, O i WG, BG, OG. Wszystkie diety uzupełniono lizyną do około $5,5 \mathrm{~g} / 100 \mathrm{~g}$ białka ogólnego, a diety jęczmienne także dodatkiem kazeiny (3\%). Określono wydajność wzrostową diet (feed efficiency ratio, FER), wartość biologiczną białka (BV), a po zakończeniu doświadczenia szczury uśpiono i izolowano jelito ślepe, określając w nim masę treści, aktywność glikolityczną i zawartość krótkołańcuchowych kwasów thuszczowych (SCFA).

FER diety owsianej była większa niż jęczmiennej z kazeiną lub diety pszennej i wynosiła odpowiednio 0,$202 ; 0,183$ i $0,162 \mathrm{~g} / \mathrm{g}(\mathrm{P}<0,01)$. BV owsa była większa niż pszenicy $(69.1 \mathrm{vs}$ $61,7 ; \mathrm{P}<0.01)$, ale mniejsza niż jęczmienia z dodatkiem kazeiny $(79,3)$. W jelicie ślepym szczurów żywionych owsem nagim stwierdzono mnicj treści pokarmowej i suchej masy niż u żywionych pszenicą i jęczmieniem (odpowiednio 1,34 vs 1,57 i $1,70 \mathrm{~g} / 100 \mathrm{~g}$ m.c. oraz 286 vs 360 i $389 \mathrm{mg} /$ 100 g m.c.; $\mathrm{P}<0,01$ ). Żywienie dietą owsianą (z największą zawartością tłuszczu) spowodowało zmniejszenie aktywności wielu enzymów glikolitycznych w jelicie ślepym. Stężenie SCFA w $1 \mathrm{~g}$ treści jelita ślepego zwierząt otrzymujących owies nagi i pszenicę było podobne i większe niż u zwierząt żywionych jęczmienjem, jednakże ogólna pula SCFA była najmniejsza w grupie owsianej. Dodatek $\beta$-glukanazy nie zwiçkszył przyrostów masy ciała szczurów, FER i BV zbóż, ale zwiększył degradację $\beta$-glukanów w jelicie ślepym, na co wskazuje wzrost stężenia SCFA w jelicie ślepym, najwyraźniejszy u szczurów otrzymujących dietę owsianą, zawierającą najwięcej $\beta$-glukanów. 